\title{
Promoting the Use of Local Literacies in EFL Pre-Service Teachers to Inspire their Teaching Practice
}

\section{Promoviendo el uso de literacidades locales en profesores en formación para inspirar su práctica docente}

Yuly Nieto'

Citation/ Para citar este Artículo: Nieto, Y. (2018). Promoting the Use of Local Literacies in EFL Pre-Service Teachers to Inspire their Teaching

Practice. Colomb. Appl. Linguistic. J., 20(2), pp. 263-273.

Received: 08-Feb.-2018 / Accepted: 14-Jun.-2018

DOI: https://doi.org/10.14483/22487085.13005

\begin{abstract}
Involving teachers and students in an interaction with their community can provide opportunities to develop literacies from a critical viewpoint. From this perspective, an active exploration and transformation of socio cultural realities can be promoted. This article will serve as a reflection on the theory of community-based pedagogies as a means of fostering pre-service language teachers' commitment in the construction of an alternative curriculum. Additionally, it calls for the appreciation of cultural context as a text for shaping and reconstructing the world, where learners explore their everyday understandings and practices, and teachers become authors of a curriculum that engages with material realities (Luke \& Woods, 2009). Thus, it promotes inquiry in early teaching experiences as a source for creating new alternatives and functional understandings through problem posing involving diversity, creativity, and reflections as the main core in the curriculum (Short \& Burke, 1991). Moreover, it supports valuing local knowledge (Canagarajah, 2005) as the foundation of an inclusive learning environment that empowers prospective teachers to envision their practice as an emancipatory exercise that demands relating the community to the classroom dynamic. Finally, it concludes that exploring socio cultural assets with the aim of enriching the EFL curriculum can inspire a context-sensitive practice that transforms both pre-service teachers and students' lived experiences.
\end{abstract}

Keywords: critical literacies, community-based pedagogies, context-sensitive curriculum, EFL teacher education for social justice, local knowledge

\section{Resumen}

Incluir a docentes y estudiantes en la interacción con su comunidad puede incrementar sus posibilidades de desarrollar literacidades críticas. Desde esta perspectiva se puede promover una exploración y transformación de realidades socioculturales. Este artículo servirá como reflexión sobre la teoría acerca de la pedagogía basada en la comunidad, como una manera de fomentar el compromiso de futuros docentes de lengua en la construcción de un currículo alternativo. Adicionalmente, invita a valorar el contexto cultural como un texto para formar y reconstruir el mundo, donde los estudiantes exploren sus prácticas y entendimientos cotidianos, y los docentes se conviertan en autores de un currículo que aborde realidades materiales (Luke \& Woods, 2009). Por lo tanto, promueve la investigación en las experiencias tempranas de enseñanza como una fuente para crear nuevas alternativas y comprensiones funcionales a través de la presentación de problemas que involucran diversidad, creatividad y reflexión, como el núcleo principal en el currículo. Asimismo, apoya la valoración del conocimiento local (Canagarajah, 2005) como la base de un entorno

1 Universidad Distrital Francisco José de Caldas, Bogotá, Colombia. yulyandreanieto@gmail.com 
de aprendizaje inclusivo que permite a los futuros profesores visualizar su práctica como un ejercicio de emancipación que exige relacionar la comunidad con la dinámica del aula. Finalmente, concluye que la exploración de los recursos socioculturales con el objetivo de enriquecer el currículo de EFL puede inspirar una práctica sensible al contexto que transforme las experiencias vividas tanto de los docentes en formación, como de los estudiantes.

Palabras clave: literacidades críticas, pedagogías basadas en la comunidad, currículo sensible al contexto, conocimiento local, formación de docentes de lengua extranjera para la justicia social

\section{Introduction}

Through the decades language education has involved itself in an exploration of foundations that respond critically to social and cultural challenges, with the aim of approaching meaningful and life-long learning experiences by considering students' environments as a way to foster meaning making. This is achieved not only by maximizing opportunities inside the classroom, but understanding and transforming possibilities outside of it (Kumaravadivelu, 2001). Therefore, the transformation of the role of the English language classroom has become a relevant discussion among teacher-researchers, since views on language have evolved to consider social practice as a defining way to construct reality, as well as to create meaning from a contextualized and local exercise (Pennycook, 2010). Thus, operating from these perspectives, teaching and learning practices should aim at evolving from traditional concepts of literacy to include the community as a text that can be explored by teachers and students through pursuing personal and collaborative inquiries. Such community inquiries allow teachers and students to become aware of the sociocultural issues that need to be transformed, providing a context-sensitive value to the English language learning process in the classroom.

The aforementioned stands for pre-service teaching experiences which address the construction of a curriculum that acknowledges community- situated pedagogies as the social structures that guide personal beliefs (Scheter, Solomon, \& Kittmer, 2003; Short \& Burke, 1991). Such pedagogies raise curiosity, awareness, a search for questions, and critical reflections using local texts to enquire into students' realities so that the EFL classroom reacts to them by integrating such findings into the language content. This is to say, pre-service teachers ought to be given a voice, as to become reflective of their own interventions, assumptions, practice and theories, for them to question the imposed curricula, as well as to transform them through exploring and connecting the local texts with the content and institutional requirements.

Furthermore, when inquiry is the educational perspective that guides the pursuit for new substantial questions, opportunities, and insights gathered throughout the process, teachers may value students' meaning construction and engage them in an examination from different viewpoints. This stance regards learning from the need to develop problem posing, rather than just problem solving skills (Freire, 1985). In other words, learning evolves from the problems that inquiry awakes in students, which emerge from the reality they feel committed and related to. For this reason, knowledge needs to be co-constructed from the social activities that occur not only within the individual, but between individuals (Wells, 1992).

Considering such foundations, this discussion is based on pre-service teachers who are in the process of designing their teaching practicum, as they are constantly making decisions about how to approach the challenges presented in the curriculum and standards to fit into their pedagogical innovations. Kumaravadivelu (2001) asserts that from the beginning, teachers have to face a continuous process of self-development through accepting and being aware of the sociocultural reality that influences classroom practices, while including both the linguistic and social needs of the learners.

The previous construct leads my initial concern upon the relevance to design a new pedagogical repertoire involving early career teachers deconstructing deficit views and discourses of 
social problems by inviting them to increase their expectations, own the curriculum, improve relationships in the classroom, and seize textual practices that eventually lead to successful outcomes (Comber \& Kamler, 2004). Since the community and local literacies can be sources of inspiration for teaching and learning, having pre-service teachers inquire into and use local literacies can broaden their potential to open their mind and reflect upon what they and the students need to be ready to read their social environment and use community assets with students in their classrooms.

\section{Critical Literacy as a Socially Constructed Practice}

Sociocultural issues are the essence of critical literacy since the process of interacting and negotiating with local texts shape an individual's perception of their own reality. This occurs by developing a sense of agency through adopting a stance on how they intend to reorganize and transform their environment with the production of new texts. All uses of language are directly related to reality; therefore, critical literacy refers to "how to write and re-write reality, transforming it through a conscious work" (Freire \& Macedo, 1987, p. 23). This can serve to introduce social change with critical literacies serving as the framework to contextualize and raise awareness.

Freire $(1987,1998)$ also calls for the need of a critical spirit in order to perceive and intervene actively in reality; otherwise individuals would be submerged in the contradictions that change brings in society, without discerning the challenges that characterize such transitions. Therefore, to be participants of social readjustments to the epoch, historical-cultural events must be integrated. Hence, the concept of literacy has to be regarded as a medium that values the historical and existential experiences inside a cultural production, considered as an integral way for people to produce, reproduce, and transform meaning. Consequently, the limited view of literacy as the ability to read and write (Barton, Hamilton, E Ivanic, 2000) or as skill development to acquire the target language, restrains a meaningful cultural appropriation that could eventually lead to an emancipatory change.
Woods, Comber E lyer. (2015) argue that approaching literacy as a standardized practice that focuses on repeated test preparation, challengefree, time-filling and thoughtless activities, offers fickle literacies that do not encourage students to construct their capacity for academic learning and for achieving complex literacies. This results in reduced opportunities for innovation, creativity, and a culturally-embedded classroom experience. Thus, a practicum experience that fosters exploration of local cultures in an attempt to integrate them in the language arts curriculum can promote the development of literacies among future teachers.

Now, taking this construct to the EFL classroom, students' practice needs to evolve from the analysis of issues which they find personally significant: their cultural context, community problems, and aspirations to rename and reconstruct their own version of the world (Luke E Woods, 2009). This means that the acquisition of literacy encompasses the acknowledgement of social ideology, everyday material relations, and the construction of the concept of justice through the production of texts (Morrell, 2003) that can be explored and questioned through reading, writing, and creating an inclusive dialogue that problematizes domination and marginalization.

To sum up, the concept of critical literacy accounts for a practice that evolves from the analysis and interrogation of the historical and cultural context of places (Comber, 2016). It problematizes social and classroom textual practices, through granting students the possibility to move from awareness to action (Pandya $\mathcal{E}$ ávila, 2013) while becoming researchers that use language to question and produce texts informed by their own reality.

\section{Local literacies and community-based pedagogies $(C B P)$}

Why should one present community and local knowledge as key concepts when discussing language curricula and critical literacy? According to Canagarajah (2005) "local knowledge has to be veritably reconstructed-through an ongoing process of critical reinterpretation, counter discursive negotiation, and imaginative application" (p. 12). 
This notion suggests that teachers should include the relevance and complexity of local knowledge to create a curriculum that integrates values, perceptions, and diversity within the community by fostering a continuous reflection that leads to a search for an alternate reality.

From this perspective, the practice of teaching and learning is concerned with collective and community actions that allow their members to make their own choices to deal with social processes, as a way to exercise their citizenship. Accordingly, the local, as political, cultural, economic and identity reality, provides the individual with the basic instruments to construct a relationship with the global. For this reason, local knowledge acts as the essence of every educational action by fostering a cultural negotiation through a constant dialogue (Mejía, 2011).

Local textual practices are resources that influence the everyday life of both students and teachers; therefore, when they are positioned in the EFL classroom, they evolve into a crossdisciplinary dialogue (Smith E Sobel, 2010a) which inspires teachers to explore problems and projects beyond their area of knowledge. This view of literacy upholds stronger connections, contributions, and engagement with the student's community.

It is suitable to take into consideration the fact that a pedagogy that is founded on place and community is not detached from the national or global. In fact, as Smith and Sobel (2010b) explain, through learning about what students are familiar with, they can get closer to phenomena that are invisible to them. An example of this argument can be taken from a research project, which aimed to position the place as the object of study (Comber, 2013), in which two professors from an underprivileged area engaged their students as researchers of the urban renewal process in their neighborhood. Cases included the demolition of old buildings, eviction, and new infrastructure, among others. Throughout the process, students produced multimodal artifacts and texts (reports for school assemblies, field trips, interviews with extended family, biographies, and descriptions of the places in school and neighborhood). Then, through visual photographs and diaries, they became analysts, which allowed them to share places where they belong, question the renewal, as well as to think about their desired school and neighborhood by exploring their own views and those of their peers.

This critical action research presents us with an alternative classroom dynamic, one which focuses on questioning power, sharing experiences, and working with a common, rather than personal, goal to create own versions of community. According to McInerney, Smyth, and Down (2011), when teachers and students examine their community and school from a critical perspective, they elicit questions about features within it, actions for betterment, monuments and heritage, invisible groups, quality of the local environment, socio-economical distribution, as well as the achievement of a just and democratic society.

The previous foundations support a pedagogy that fosters a sense of possibility, agency, and transformation by recognizing the assets in the place and space of study (Comber, 2017). This idea is mirrored by Rincón and Clavijo (2016) who report on their qualitative study focused on analyzing the ways in which community inquiry provides students with opportunities to discover socio-cultural issues in their neighborhoods through a multimodal experience. These authors carried out a project in a low-socio economic public school with a sociocritical research lens. The study began by mapping the community for the identification of an issue which continued with documentation through interviews, note-taking, and questionnaires. Finally, students created multimodal texts to present their findings creatively in a blog that fostered peer discussion regarding possible solutions to the problematic situations. The findings reveal that students were intellectually and emotionally engaged when they critically reflected on their role within the community, engaging in resiliency practices to overcome social issues experienced in their barrios.

Such local inquiry justifies that the EFL classroom experience can respond to students' world by disengaging from the view of texts as isolated from context. When teachers expose their students to their challenging settings, based on a 
pedagogy of place, they envision the emancipatory role of language practices in their students' lives. This opposes the assumption that teacher, student, and school achievement can be measured by isolated, individualistic, and quantifiable classroom routines (Greenwood, 2013; Gruenewald, 2003a).

With all the components mentioned above, Gruenewald (2003b) invites teachers to demonstrate that places are pedagogical; that is, acknowledging that "as centers of experience, places teach us about how the world works and how our lives fit into the spaces we occupy" (p. 10). Thus, to understand our relationship with the world, we need to value place by exploring it through ongoing social inquiry. This, in turn, becomes the principle for and education practice that appreciates researching for cultural well-being (King, 2008).

Additionally, in order to approach a placebased pedagogy, it is suitable to highlight its dimensions: perceptual, sociological, ideological, political, and ecological. (Gruenewald, 2003b). Perception suggests that schools have to come up with strategies for teachers and students to perceive and establish connections with their surroundings. Now, to say that places are sociological is to recognize that we have to become aware of our role as citizens and participants in the sociopolitical process that a place constitutes; leading to the ideological dimension, when finding out about the interdependent economic, political, ideological, and ecological relationship among places near and far. Teachers and students must enter the context of their regions, cities, neighborhoods, and schools to inquire about marginalization, the multiple forms of oppression, the possibilities for resistance, and transformation. As such, they may begin to move toward a concept of justice in education, perceived in a community with possibilities to the marginalized, while regarding the ecological dimension from the exploitation of people, and the exploitation of their environment.

Furthermore, when place along with cultural issues acts as the core of the curriculum, teachers and students can immerse themselves in the investigation of their society with a broader view by including different disciplines. Sharkey, Clavijo, and
Ramirez (2016) conducted a study of community based literacies in language teacher education which included experienced teachers from social studies, chemistry, Spanish language arts, and English from three public schools in Bogotá. They aimed at discovering how they developed and implemented community-based pedagogies, after designing projects that emerged from their students' problemposing of their community. This way, teachers could meet the institutional standards by valuing local knowledge as a curriculum resource.

Projects such as understanding the semiotics of graffiti, the analysis of the socioeconomic reality of the students' neighborhood, interviewing workers and families, and finding out about Colombian history from their own and their families' voices, display, as described by the participants, that appreciating local knowledge as a curriculum resource increases teachers' autonomy and ownership, as well as students' motivation, engagement, and family involvement.

Thus, I conclude that CBP focuses on assembling the local context of interaction outside the classroom so as to construct a teaching practice and curriculum that is informed by researching the community assets. Sharkey (2012) defines CBP as follows:

Curriculum and practices that reflect knowledge and appreciation of the communities in which schools are located and students and their families inhabit. It is an asset-based approach that does not ignore the realities of curriculum standards that teachers must address, but emphasizes local knowledge and resources as starting points for teaching and learning. (p.11)

That is to say, through place-based learning, meeting the standards becomes a collaborative task of both teachers and students who involve the community as partners in the curriculum design (Demarest, 2014). For this to be accomplished, the teacher needs to envision part of the outcome and provide a space to create assessment tools together. The assessment criteria that he or she proposes can include: literacy skills, interpretation of place, collaboration, action taking, and reflection. 
Accordingly, Demarest (2014) suggests that community based experiences require the following curricular elements of local learning: "personal connections are the foundation of all learning, local investigations deepen subject understanding, build holistic understanding of places, as well as an opportunity for civic engagement” (p. 43).

To approach an awareness that emerges from place-based explorations, I refer to the study carried out by Sharkey and Clavijo (2012) on promoting the value of local knowledge in ESL/ EFL teacher education through community-based field assignments. In this project, the authors found that through mapping, visiting, and interviewing people and places that students regularly meet (parks, cafeterias, discos, grocery stores, shopping malls), the participant teachers could later discover resources for integrating and rethinking community literacy practices that became central in the curriculum.

As a result, the field experience fostered creativity and expanded teachers' resources about how to connect students' backgrounds with the curriculum, as well as to enhance the interactions between teachers, students, family, and community. Moreover, they raise awareness on identifying assets that enrich curricular content, and allow the teacher to change their deficit view on language teaching to promote student agency.

\section{Pre-service Language Teacher Practicum: Structure and Focus of an Education for Social Justice}

Language teacher education from a social justice perspective generates possibilities to organize the curriculum collaboratively through the establishment of a bond between the classroom experiences of teachers and students and the exploration of community resources and members. This view stimulates sympathy towards diversity, thus creating an inclusive learning environment which stands for a negotiation of experiences that value invisible voices, by giving them the chance to question, propose, and imagine the path to witness transformations that encompass just opportunities.
From these foundations, teacher education programs provide prospective teachers with spaces to conceptualize justice by rethinking how realities such as race, class, or poverty build students' personal narrative. This requires attending to their needs and stories differently so that the classroom grants available opportunities to help students discover their capacities. As McDonald and Zeichner (2009) assert, "being just is not simply a matter of divvying up the pie evenly, but rather taking into consideration which individuals at the table need more pie, or a different pie entirely, in order to be successful" (p. 600). This notion suggests that when the teaching program urges and guides future teachers to shape their practice based on the social context that informs their decisions and actions, it contributes to the construction of the role of community teachers (Murrell, 2001) who contextualize the knowledge of the community, culture, and identity of the students and families they work with to build a successful teaching practice in diverse settings.

Hence, learning is understood within the different collective contexts in which students interact to construct knowledge (Scheter, Solomon, $\varepsilon$ Kittmer, 2003). Such interaction provides community resources and needs that can be explored while providing training in research skills. This allows pre-service teachers to locate reliable background information as well as to represent the voices and life modes in the community.

Moreover, fostering situated interaction would help teachers develop sensitivity, consciousness, and competencies that lead them to work collaboratively with others in the academic environment, as well as in the community through incorporating a set of shared values and social relations immersed in local contexts. Thus, EFL pre-service teachers would not only be concerned with language acquisition, but also with its use and applications to enhance their students' lives outside of the classroom setting.

Following this conceptual framework, teaching is regarded as a political exercise. As such, the practicum needs to support the process of empowering practitioners to understand their role as community teachers. Therefore, EFL 
programs can promote a community-oriented vision, by focusing and being structured around three main aspects: conceptualizing CBP, creating an alternative curriculum, and fostering teachers' local inquiry through community immersion. This can be achieved by carrying out a field investigations that allow to understand the dynamics in a community, through the consideration of its physical spaces, individuals, local economy, institutions and associations (Kretzman \& McKnight, 1993).

In a study of a reflective practice conducted by observing pre-service teachers (PSTs) implementing a CBP curriculum, Johnston and David (2008) found that conceptualizing CBP was initially considered a complex task. This was perceived in some PSTs unwillingness to complete didactic units. However, as PSTs began adapting the units to their students by getting closer to their feelings, they perceived the CBP projects as a possibility for children to explore their places with their families and peers. This allowed them autonomy in their own process to accomplish the goals toward which the unit aimed. This was reflected in their engagement with innovative projects as a result of discovering their own way through the complexity of the concept of CBP.

The findings displayed in this study provide key elements to bear in mind when implementing a project that includes the PSTs establishing links with community and curriculum: It is important to construct collective understandings and intentions of CBP in the EFL classroom by guiding future teachers in the exploration of the concept on their own, offering the required guidance and positive feedback, and reinforcing communication channels to face unavoidable tensions.

Furthermore, as previously mentioned, community immersion in the EFL teaching practicum permits future teachers to support their practice with commitment towards social justice by appreciating what comes with each student's learning process: families, communities, affordances, and difficulties. An example can be observed in the longitudinal study carried out by McDonald, Bowman, and Brayko (2013) which focused on examining two cohorts of teacher candidates to observe the factors that influence pre-service teachers to enact CBP, as well as what they learn in community-based organization (CBO) field placements.

The researchers, who were professors at the teaching program, conducted and documented reviews from the first quarter of preparation into their first year of teaching. Their findings revealed that when the candidates were exposed to CBO contexts, they developed deeper understandings of community and children, as well as more complex definitions of diversity. Additionally, they developed the ability to see the school from an out-of-class perspective, becoming more attentive to learning contexts. In consequence, it can be concluded that EFL programs require a commitment to act as mediators in the kind of experiences that shape teacher participation and willingness to be immersed in a contextual practice.

The previous example affirms the power of considering community research as substance in preparation programs, since understanding the surroundings of the young population prospective teachers will work with will lead them to become more effective educators (Cochran-Smith, 2005; Zeichner $\varepsilon$ Conklin, 2008) who acknowledge the motivations of their students, and have the potential to deal with the challenges presented in the place they inhabit (Richmond, 2017).

Further, community focus in education programs provides tools for future teachers to critique official standardized models which perpetuate overgeneralizing realities that do not fit in locally produced knowledge. This may lead to the reinforcement of social inequalities (Gonzalez, 2007) and restraining the teacher from being considered a valuable member of decision-making, teaching effectively, as well as becoming agents of their development.

Furthermore, concerning the promotion of the value of community knowledge, university-level students need to be involved in a campus community partnership (Strand, Marullo, Cutforth, Stoecker, E Donohue, 2003) that promotes action for social change, while equally sustaining inequality and 
injustice. In other words, university practice would be concerned with community-based research that attends to locally-identified needs through a process of collaboration among academic researchers and community members, validating multiple sources of knowledge, methods of discovery and dissemination, and achieving social justice (Strand, 2000).

Additionally, as Clavijo (2014) posits, promoting the use of projects with local communities as resources in a LTE program accounts for curriculum transformation, leading to a reconsideration of activities to solve content related problems. This statement triggers different insight from the teachers and students over a more active participation in using community assets. As a result, appreciating local knowledge to construct curriculum increases teachers' autonomy and ownership, as well as student motivation, engagement, and family involvement.

Considering the focus on critical curriculum construction, the practicum experience enables teachers to reflect on the significance of the EFL curriculum as a way to transform standards-based pedagogical practices and build up new repertoires from collaborative inquiry within the teaching community. Clavijo et al. (2004) refer to teachers adopting critical curricular perspectives in the way they think about their students' needs, as well as reflect on their curricular innovations and how they adjust their pedagogical practices.

In their interpretive qualitative study, they identified the process of innovation, in terms of intervention, planning, and implementation, of 19 teachers from public schools in Bogotá through professional development programs on literacy. In this way, the teachers became involved in research experiences with their colleague participants from the same schools. The outcomes of this project reflect that the innovative pedagogical actions proposed by the teachers were addressed to enhance learner's literacy development by including students, parents, and teachers in the different practices. In addition, they planned and managed their curricular innovations by working collaboratively on the adjustments to the curriculum.
When considering the structure of a teaching practicum, the interaction it provides can be considered from two perspectives: professional development schools (PDS) and communityoriented settings (Boyle-Biase \& McIntyre, 2008) with both views acting as reforms to the traditional models in which theory is separated from practice. In this fashion, community-oriented experiences affirm diversity, build community, and question inequity by recognizing places from an assetbased approach. Hence, local interaction provides opportunities to gain cultural insight from future students' values.

On the other hand, PDS stand for principles that allow teachers to master content, read their students' needs, collaborate with peers on inquiry, gain expertise in constructed learning, and use valid forms of assessment to determine what students learned-all of which leads to the development of a culture of academic expertise.

Boyle-Biase and McIntyre (2008) propose a community-oriented vision for PDS in teacher education programs in which teacher inquiry stresses attention to equity, diversity, family, and community needs. This framework would help develop a practice for: teachers with heart, who consider local issues as their own; teachers with connections, who participate in community committees; and teachers with knowledge, who manage to shape local knowledge into the curriculum. Accordingly, enabling future teachers to be immersed in a culturally-responsive teaching practice leads them to self-reflect on their profession beyond subject-matter specialists by fostering their own development form the commitment to research about local assets and issues.

For such a perspective to be visible, it is paramount that teacher education programs initiate a culture of evidence (Cochran-Smith $\mathcal{E}$ Zeichner, 2009 that elucidates the impact they are making in terms of teacher quality and student learning. Consequently, these programs would be documenting and ensuring that preservice teachers initiate their professional lives with the capacity to work on a diverse learning community. 
That way, the conception of teacher preparation programs based on considering capacity only from the dimensions of knowledge, skills, and dispositions is challenged to integrate social justice theories and practices, as argued by Grant and Agosto (2008), given that future teachers need to be ready to become informed by the particular community that will allow them to pose questions and take action from curriculum. That is, becoming conscious about their role as agents of change in the institutions the will contribute to and will prepare them to become critical educators (Howard E Aleman, 2008).

To sum up, in order for PDS to work from a social justice perspective, teaching programs need to provide pre-service teachers with the discussion of issues, concepts, and ideas building the curriculum with a justice view. In addition, they need to encourage field experiences, and encounters with community members, that allow them to witness inequities (Sierra Piedrahita, 2016) as to enhance their students' opportunities, by keeping high expectations as to inspire them to meet their goals.

\section{Conclusion}

Empowering future teachers to build an innovative practice which envisions teaching as a powerful exercise grants them the possibility to consider themselves important actors in curriculum construction. Such vision requires them to be social enquirers of local texts and to build from a social justice perspective that addresses local values. This provides an opportunity for them to become active advocates of transformations in their social reality.

Moreover, becoming aware of local literacies fosters a critical reflection on the role of the teacher in their communities. The connection with the local represents an inspiration for professional development, teachers' stances on education, language learning, and critical literacy. Thus, preservice teachers end up problematizing social issues, which become essential components in the process of planning and promoting further personal inquiries with students.

\section{References}

Barton, D., Hamilton, M., E Ivanic, R. (2000). Situated literacies: Reading and writing in Context. New York, NY: Routledge.

Boyle-Biase, M., \& McIntyre, D. (2008). What kind of experience? Preparing teachers in PDS or community settings. New York, NY. Routledge.

Canagarajah, S. (2005). Reclaiming the local in language policy and practice. Mahawh, NJ: Lawrence Elbaum Associates.

Clavijo, A. (2014). Implementing community based pedagogies in a language teacher education program in Colombia. Bogotá, Colombia: Universidad Distrital.

Clavijo, A., Guerrero, C., Torres, C., Ramirez, L., \& Torres, N. (2004). Teachers acting critically upon the curriculum: Innovations that transform teaching. Íkala: Revista de lenguaje y cultura, 9(15), 11-41.

Cochran-Smith, M. (2005). Teacher educators as researchers: Multiple perspectives. Teaching and Teacher Education, 21(2), 219-225. https://doi. org/10.1016/j.tate.2004.12.003

Cochran-Smith, M., $\&$ Zeichner, K. M. (Eds.). (2009). Studying teacher education: The report of the AERA panel on research and teacher education. New Jersey. Routledge.

Comber, B. (2013). Schools as meeting places: Critical and inclusive literacies in changing local environments. Language Arts, 90(5), 361-371.

Comber, B. (2016). Critical and inclusive literacies: Pedagogies of belonging. In B. Comber (Ed.), Literacy, place, and pedagogies of possibility (pp. 33-63). New York, NY: Routledge.

Comber, B. (2017). Literacy geography and pedagogy: Imagining translocal research alliances for educational justice. Literacy Research: Theory, Method, and Practice,1-20. https://doi. org/10.1177/2381336917717479

Comber, B., \& Kamler, B. (2004). Getting out of deficit: Pedagogies of reconnection. Teaching Education, 15(3), 293-310. https://doi. org/10.1080/1047621042000257225

Demarest, A. (2014). Place-based curriculum design. New York, NY: Taylor $\mathcal{E}$ Francis.

Freire, P. (1985). The politics of education. South Hadley, MA: Bergin \& Garvey. https://doi.org/10.1007/978-1349-17771-4

Freire, P. (1987). Education for critical consciousness. New York, NY: Continuum. 
Freire, P. (1998). Pedagogy offreedom: Ethics, democracy, and civic courage. USA: Rowman E Littlefield.

Freire, P., E Macedo, D. (2005). Literacy: Reading the word and the world. London: Routledge.

Gonzalez, A. (2007). Professional development of EFL teachers in Colombia: Between colonial and local practices. Íkala: Revista de Lenguaje y Cultura, 12(18), 309-332.

Grant, C. A., E Agosto, V. (2008). Teacher capacity and social justice in teacher education. Educational Leadership and Policy Studies Faculty Publications, 5, 175-199.

Greenwood, D. (2013). A critical theory of place-conscious education. In J. Dillon \& M. Brody (Eds.), International handbook of research on environmental education (pp. 93-100). New York. Routledge. https://doi. org/10.4324/9780203813331.ch9

Gruenewald, D. A. (2003a). Foundations of place: A multidisciplinary framework for placeconscious education. American Educational Research Journal, 40(3), 619-654. https://doi. org/10.3102/00028312040003619

Gruenewald, D.A.(2003b). Thebest of bothworlds: Acritical pedagogy of place. Educational Researcher, 32(4), 3-12. https://doi.org/10.3102/0013189X032004003

Howard, T. C., \& Aleman, G. R. (2008). Teacher capacity for diverse learners: What do teachers need to know? In M. Cochran-Smith \& D. McIntyre (Eds.), Handbook of research on teacher education: Enduring questions in changing contexts (pp. 57174). New York, NY: Routledge.

Johnston, R., \& Davis, R. (2008). Negotiating the dilemmas of community-based learning in teacher education. Teaching Education, 19(4), 351-360. https://doi.org/10.1080/10476210802436492

King, J. E. (2008). Critical and qualitative research in teacher education: A blues epistemology for cultural well-being and a reason for knowing. In $M$. CochranSmith, S. Feiman-Nemser, D. J. McIntyre, \& K. E. Demers (Eds.), Handbook of research on teacher education (pp. 1096-1132). New York, NY: Routledge.

Kretzmann, J., \& McKnight, J. (1993). Building communities from the inside out: A path toward finding and mobilizing a community's assets. Evanston, IL: Institute for Policy Research.

Kumaravadivelu, B. (2001). Toward a postmethod pedagogy. San José, CA: San José State University.

Luke, A., \& Woods, A. (2009). Critical literacies in schools: A primer. Voices from the Middle, 17(2) 9-18.

Mejías Jiménez, M. R. (2011). Educaciones y pedagogías críticas desde el sur. Cartografía de la Educación popular. Lima: Editorial Quimantú.
McDonald, M. A., Bowman, M., \& Brayko, K. (2013). Learning to see students: Opportunities to develop relational practices of teaching through communitybased placements in teacher education. Teachers College Record, 115(4).

McDonald, M., E Zeichner, K. M. (2009). Social justice in teacher education. In W. Ayers, T. M. Quinn, E D. Stovall (Eds.), Handbook of social justice in education (p. 595-610). New York, NY: Routledge.

McInerney, P., Smyth, J., \& Down, B. (2011). 'Coming to a place near you?' The politics and possibilities of a critical pedagogy of place-based education. AsiaPacific Journal of Teacher Education, 39(1), 3-16. https://doi.org/10.1080/1359866X.2010.540894

Morrell, E. (2003). Writing the word and the world: Critical literacy as critical textual production. 54 ${ }^{\text {th }}$ Annual Meeting of the Conference on College Composition and Communication. New York, NY.

Murrell, P. (2001). The community teacher: A new framework for effective urban teaching. New York, NY: Teachers' College Press.

Pandya, J., E Ávila, J. (2013). Moving critical literacies forward: A new look at praxis across contexts. New York, NY: Routledge.

Pennycook, A. (2010). Critical and alternative directions in applied linguistics. Australian Review of Applied Linguistics, 33(2), 16-1. https://doi.org/10.2104/ aral1016

Richmond, G. (2017). The power of community partnership in the preparation of teachers. Journal of Teacher Education, 68(1), 6-8. https://doi. org/10.1177/0022487116679959

Rincón J., \& Clavijo-Olarte, A. (2016). Fostering EFL learners' literacies through local inquiry in a multimodal experience. Colombian Applied Linguistics Journal, 18(2), 67-82. https://doi. org/10.14483/calj.v18n2.10610

Sharkey, J. (2012). Community-based pedagogies and literacies in language teacher education: Promising beginnings, intriguing challenges. Íkala, 17(1), 9-13.

Sharkey, J., \& Clavijo-Olarte, A. (2012). Promoting the value of local knowledge in ESLEFL teacher education through community-based field assignments. In B. Medrado \& C. Reichmann (Eds.), Projetos e praticas na formacao de professors de lingua inglesa (pp. 39-58). Paraiba, Brasil: Editora Universitaria.

Sharkey, J., Clavijo, A., E Ramírez, M. (2016). Developing a deeper understanding of community-based pedagogies with teachers: Learning with and from teachers in Colombia. Journal of Teacher Education, 67(3), 1-14. https://doi. org/10.1177/0022487116654005 
Short, K., \& Burke, C. (1991). Creating curriculum: Teachers and students as a community of learners. Portsmouth, $\mathrm{NH}$ : Heinemann.

Sierra Piedrahita, A. M. (2016). Contributions of a social justice language teacher education perspective to professional development programs in Colombia. PROFILE: Issues in Teachers' Professional Development, 18(1), 203-217. https:// doi.org/10.15446/profile.v18n1.47807

Schecter, S. R., Solomon, P., \& Kittmer, L. (2003). Integrating teacher education in a communitysituated school agenda. In S. R. Schecter E C. Cummins (Eds.), Multilingual education in practice: Using diversity as a resource (pp. 81-96). Portsmouth, $\mathrm{NH}$ : Heinemann Books.

Smith, G., \& Sobel, D. (2010). Placed and communitybased education: Definitions and Antecedents. In Placed and community-based education in schools. London. Routledge, 21-31.

Strand, K., Marullo, S., Cutforth, N., Stoecker, R., \& Donohue, P. (2003). Principles of best practice for community-based research. Michigan Journal of Community Service Learning, 9(3), 5-15.
Strand, K. (2000). Community-based research as pedagogy. Michigan Journal of Community Service Learning, 7, 85-96.

Wells, G. (1992). Language and the inquiry-oriented curriculum. Annual Meeting of the National Council of Teachers of English. Louisville, KY.

Woods, A., Comber, B., E lyer, R. (2015). Literacy learning: Designing and enacting inclusive pedagogical practices in classrooms. In Inclusive Pedagogy Across the Curriculum (pp. 45-71). Emerald Group Publishing Limited. https://doi.org/10.1108/S1479363620150000007009

Zeichner, K. M., \& Conklin, H. G. (2008). Teacher education programs as sites for teacher preparation. In $M$. Cochran-Smith, S. Feiman-Nemser, D. J. McIntyre, $\mathcal{E}$ K.E. Demers (Eds.), Handbook of research on teacher education: Enduring questions in changing contexts (pp. 269-289). New York: Routledge. 